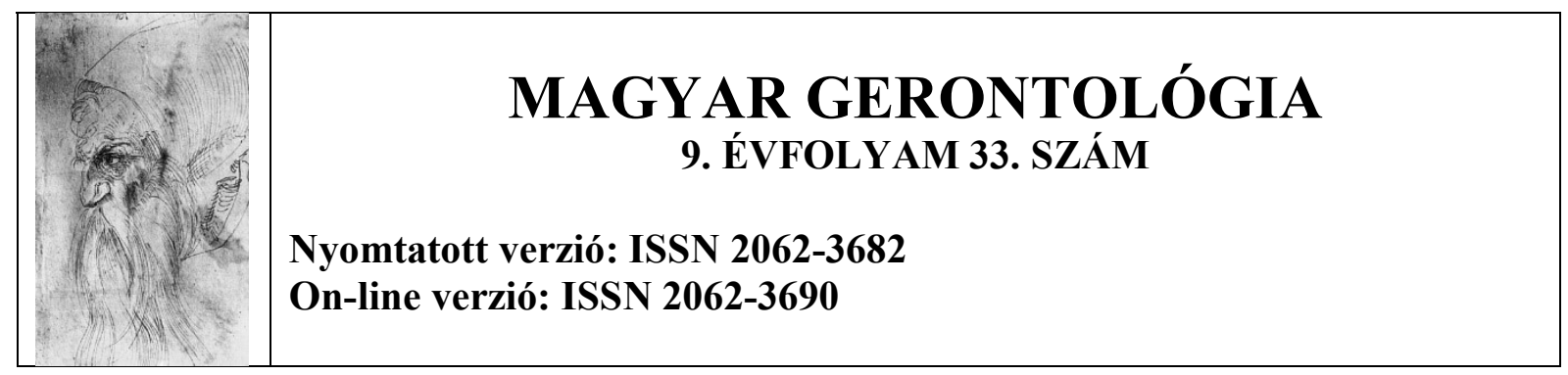

\title{
AZ IDŐSKORI SZERENCSEJÁTÉK ZAVAR
}

\author{
dr. Pék Gyözö PhD
}

Kulcsszavak: szerencsejáték zavar, időskori szerencsejáték, személyiség, szituációs faktorok

\section{Összefoglalás}

Tanulmányunk célja az időskori szerencsejátékkal kapcsolatos vizsgálatok és tanulmányok rövid összefoglalása és elemzése. A fiatal és felnőttkori szerencsejátékkal kapcsolatosan kiterjedt kutatások állnak rendelkezésre, ismerjük a kórkép kialakulásában és fennmaradásában szerepet játszó fontosabb demográfiai jellemzőket, személyiségfaktorokat és terápiás lehetőségeket. Az időskori szerencsejátékkal kapcsolatosan kevés a vizsgálati eredmény külföldön és Magyarországon még nincs kifejezetten 65 év feletti szerencsejátékosokra fókuszáló tanulmány. Ezért ebben az összefoglalóban kizárólag külföldi vizsgálatokra támaszkodhatunk, a speciális minta következtében azonban a tanulmányok és következtetések száma korlátozott. Az eredmények alapján az időskori szerencsejáték különbözik a fiatal és serdülőkori szerencsejátéktól.

\section{Summary}

The aim of our study is to summarize and analyze the researches about elderly gambling. There are extensive studies about adolescents and adult gambling, we know demographic factors, motivation base and personality traits which contribute to the initiation and maintenance of problem.

There are only a few studies dealing with elderly gambling and there is no study focusing gamblers above 65 in Hungary. Therefore in our study we can use articles from abroad. According to the results elderly gambling differs from adolescents and adult gambling regarding many aspects. 


\section{Bevezetés}

A szerencsejáték zavart a DSM-V a Nem szerrel kapcsolatos zavarok közé sorolja (Nussbaum, 2013). A szerencsejáték zavar fázisai a játék előtti fokozódó feszültség és késztetés, a játék közbeni átmeneti feszültségcsökkenés, izgalom, a játékot követően a veszteségek következtében erös büntudat. Kognitív beszükülés jellemző a szerencsejátékkal kapcsolatos ingerekre, a személy a játékkal foglalkozik, stratégiákat készít, valószínűséget számol, elhanyagolja feladatait, kötelességeit, szociális kapcsolatait. Gyakori a relapszus és a szerencse üldözése, melynél a veszteségek esetén visszatér a pénzt visszanyerni (Körmendi és Kuritárné, 2007; Körmendi, 2011). A kutatások alapján az időskori szerencsejáték zavar számos tekintetben különbözik a serdülő és felnőttkorban induló szerencsejáték zavartól.

\section{Az időskori szerencsejáték zavar prevalenciája}

A problémás szerencsejáték kialakulásának kockázata az életkorral csökken (Johansson és mtsai 2009). A szerencsejátékok és a szerencsejátékkal kapcsolatos helyek elérhetőségének növekedésével az szerencsejátékkal játszók aránya nő az idősek között (Nixon és mtsai 2005). A szerencsejáték zavar élettartam prevalenciája 1-2\% fiatal és középkorúak esetében (Volberg, 1994). Az időskori szerencsejátékkal kapcsolatos prevalenciaértékeket több változó is befolyásolja. A prevalenciát különböző szerzők eltérő eszközökkel mérték, és az minta alsó életkori határa is gyakran eltért. Philippine és Vallerand (2007) a Revised South Oaks Gambling Screen segítségével 1.2\%-os prevalenciát mértek a kóros játékszenvedélyre, és 1.6\%-os prevalenciát a szubklinikai szintre vonatkozólag 55 évnél idősebbeknél. Az időskori szerencsejáték prevalenciája tehát enyhén alacsonyabbnak bizonyult, mint a felnőttkori szerencsejáték előfordulási gyakorisága. Ugyanakkor két tanulmány az idősebbek között magasabb szerencsejáték függőség prevalenciát mért (McNeilly és Burke, 2000; Bazargen és mtsai 2001). Észak-Amerikában az időskori szerencsejáték-függőség prevalenciája 2\%-17\%-ig terjed az alkalmazott mérőeszköztől és a régiótól függően (Tira, Jackson és Tomnay, 2013). A prevalenciaarány feltehetően párhuzamosan növekszik a szerencsejátékok elérhetőségével és legalizácijával, például a National Gambling Impact Study Commission felmérései szerint 1998-ban a 65 évesek és idősebbek 50\%-a játszott már szerencsejátékkal kaszinóban, míg például 1975-ben ez a szám csak 23\% volt (National Gambling Impact Study Commission, 1999). Az eredmények alapján úgy tünik, hogy a szerencsejáték függőség prevalenciája esetében a nem és az életkor között interakció található, a prevalenciaérték jellemzően magasabb a fiatalabb korosztályban, mint az idősebb korosztályban a férfiakat tekintve. Az idősebb nők esetében azonban ennek ellenkezője igaz, ott tehát az idősebb korosztályban 
magasabb prevalenciaértékeket találunk, mint a fiatalabb korosztályokban (Volberg és mtsai 2010).

\section{Az időskori szerencsejáték zavar kutatási problémái}

Jellemző kutatási probléma az időskori szerencsejáték életkori határainak meghatározása. A legtöbb szerző 65 éves életkori határtól vizsgálja a jelenséget, néhány esetben azonban ettől kisebb életkori határt (jellemzően 55 vagy 60 év) alkalmaztak a szerzők. A konszenzus hiánya nehezen összehasonlíthatóvá teszi különböző szerzők eredményeit. Mindazonáltal a legtöbb tanulmány egyetért abban a tekintetben, hogy a késői életévekben induló szerencsejáték legalább részben eltérő motivációs háttérrel magyarázható, mint a serdülőkorban, vagy felnőttkorban induló szerencsejáték. További módszertani nehézséget jelent, hogy egyes tanulmányokban szerencsejáték zavarral diagnosztizálható idősek alkották a mintát, míg más tanulmányokban a szerencsejátékot rekreációs céllal használó időseket vizsgáltak. 65 év feletti szerencsejátékosokat toborozni nehézséget jelent, a kutatások jellemzően kis elemszámmal dolgoznak, így korlátozott a lehetőség csoportosító változók használatára (például a preferált játéktípus alapján alcsoportok létrehozására).

\section{Vonatkozó kutatások}

Az időskori szerencsejátékot kiváltó tényezők lehetnek demográfiai jellemzők, személyiség jellemzők, a szerencsejátékok környezeti jellemzői, és a szerencsejátékok strukturális jellemzői. A faktorok komplex interakciója határozza meg a bevonódás mértékét és a szerencsejátékkal kapcsolatos problémák súlyosságát.

\section{Demográfiai jellemzők}

Moufakkir (2012) kaszinókba járó szerencsejátékosokat vizsgált különös tekintettel az idősebb korosztályra, ebbe a csoportba azokat sorolták, akik legalább 65 évesek voltak. Demográfiai jellemzők tekintetében az idősebb szerencsejátékosok egyedülálló, alacsony jövedelemmel rendelkezők, gyermekeiktől külön élnek. A szerencsejátékra fordított összeg tekintetében nem különböztek szignifikánsan a többi életkori csoporttól. Érdekes eredmény azonban, hogy a szerencsejátékon elveszített pénz mennyisége az idősebb korosztályban jelentősen kevesebb, mint a többi életkori csoportban. Az idősek leggyakrabban rekreációs és szociális célokból látogatták a kaszinókat. A szerencsejátékkal kapcsolatos tájékozódás céljából az internetet kevésbé vették igénybe, mint a többi korosztály. 
Grant és mtsai (2009) alapján kevésbé jellemző a szülők szerencsejátékkal kapcsolatos problémája, mint a fiatalabb életkorokban induló szerencsejáték esetében.

Potenza és mtsai (2006) szerencsejátékkal kapcsolatos segélyvonalat hívók mintájában az idősebb korosztály jellemzőit próbálták azonosítani. 1018 telefonhívásból 168 idősektől érkezett (16.5\%). Az idősebb szerencsejátékosok kevésbé valószínüleg említettek szorongást, családi problémákat, adósságot a szerencsejátékos tevékenységükkel kapcsolatban. Jövedelmük alacsonyabb és játéküléseik hosszabbak, mint a fiatalabb korosztályoknál. Mindezek az adatok megfontoltabb. átgondoltabb szerencsejátékos viselkedésre utalnak. A hosszabb játékülések alacsonyabb tétekkel vagy megfontoltabb játékstílussal érhetőek el, tovább kisebb számú családi és adósággal kapcsolatos probléma is racionálisabb és tudatosabb pénzmenedzselésre utal. Ezt a gondolatmenetet a „Szerencsejátékos viselkedés” részben bővebben tárgyaljuk.

Granero és mtsai (2014) a problémás szerencsejáték és az életkor összefüggéseit vizsgálták 2309 fős terápiás segítséget kereső mintán. Az idősebb szerencsejátékosra inkább jellemzőbbnek találták a komorbid kórképek jelenlétét. A pénzügyi gondok leginkább a középkorúak között jelentek meg. Nőknél inkább jellemző a szerencsejáték későbbi indulása, és a kontrollcsoporttal összehasonlítva személyiségprofiljukra jellemző a magasabb impulzivitás, újdonságkeresés, kockázatkerülés és alacsonyabb önirányítottság. A szerencsejátékkal kapcsolatos problémák (adósságok és nagyobb eljátszott összegek) leginkább a középkorú korosztályt jellemezték.

Petry (2001) azt találta, hogy a késői életkorokban induló szerencsejáték inkább nőkre jellemző, és inkább a munkavállalás területén okoz problémákat, mint a szociális területen.

\section{Szerencsejátékos viselkedés}

Moufakkir korábban említett kutatásában találunk az idősebbek korosztályában óvatosabb, tudatosabb szerencsejátékra utaló jegyeket, mivel hasonló mennyiségü pénzt fordítottak szerencsejátékra, mint a többi korosztály, azonban kevesebbet veszítettek (2012). Az eredmények konzisztensek Beits, Salthouse és Davis 2014-es eredményeivel, amelyben az Iowa Gambling Task-ben nyújtott teljesítményt hasonlították össze életkori csoportonként. Az fiatal és idős korosztályt összehasonlítva különböző döntési stratégiákat találtak. A fiatalok gyengébb teljesítménye impulzív döntéshozási stratégia eredményeként jelent meg. Ezzel szemben az idősek jellemző stratégiái a veszteségek elkerülése és a nyeremény maximalizálása voltak, amely magyarázhatja Moufakkit és Potenza eredményeit. Grant és mtsai (2009) szintén az időskorban induló szerencsejátékról írták, hogy kevésbé valószínűen eredményez pénzügyi gondokat, 
A szerencsejátékok szituációs jellemzőinek hatása az idős szerencsejátékosokra

A szerencsejátékok szituációs jellemzői olyan környezeti jellemzők, melyek hatására a játékos motiválódhat a szerencsejáték irányába. Feltehetőleg az addikció kialakulásának kezdeti szakaszában játszanak fontos szerepet a szituációs jellemzők (Körmendi, 2009).

Az idős és nyugdíjas kort elérők várható élettartalma az egészségügyi ellátásnak és az emelkedő létkörülményeknek megfelelően nő, ugyanakkor az aktív tevékenységek száma csökken. Az egyik lehetséges időtöltés a szerencsejáték, amely természetéből eredően izgalmakat, élményt, közösséget hoz létre az idős személy számára, és mozgásban korlátozottak számára is elérhető lehet. Egy vizsgálatban az idősek a szerencsejátékos viselkedés leggyakoribb okaként az „otthonról kimozdulást” és a társaságot említették (American Gambling Association, 2000).

A kaszinók alkalmas közegnek bizonyulnak a magány és az unalom érzéseinek elüzésére. Itt az idős szerencsejátékosok befogadó szociális közegben játszhatnak, mely érzelmileg támogatja és racionalizálja szerencsejátékos viselkedésüket. A kaszinókban található luxuskörülmények és kiszolgálás a nárcisztikus szükségletek kielégítését szolgálja (Kranes, 1995). Jellemző az ingerek sürítése, társas interakciók történnek zárt ablak nélküli helyiségekben, változatos fény és hanghatások érik az idős játékost, amelyek hatására a viselkedés automatikussá és kevésbé tudatossá válik. A komfortszolgáltatások közé tartoznak a különféle bónuszjegyek, ingyenes étel és italszolgáltatás, rendezvények. Néhány szerző igazolta, hogy a komfortszolgáltatások fontos motivációs bázist jelentenek az idősebb szerencsejátékosok számára (Moufakkir, 2012).

McNeilly és Burke 2001-ben 65 év feletti szerencsejátékosokat tanulmányozott, céljuk a kaszinó, mint szocializációs közeg vizsgálata volt. 6957 fös mintájukból 16\% látogatta több, mint havi alkalommal a kaszinókat. Azokban az intézményekben, ahonnan a kaszinók által szervezett buszok szállították a jelentkezőket a kaszinóba nagyobb részvételi arányt találtak. eredményeik szerint az idős személyek szabadidős tevékenységeinek száma csökkent a kaszinós szerencsejátékok javára, amely feltehetőleg a kaszinók magasabb elérhetőségének és a szervezett buszjáratoknak köszönhetö. Az idősek arról számoltak be, hogy a kaszinóban barátságos, elfogadó közeggel találkoztak, ahol életkoruk nem jelentett problémát. Az idősek iránti toleráns, elfogadó közeg pozitív megerősítést jelentett a kinti társadalomban tapasztalt attitüdökkel szemben, csökkent az izoláció, a magány és a feleslegesség érzése. A jutalmazó szociális környezet látogatása tehát coping mechanizmusként müködhet a szerencsejátékos karrier előrehaladtával. Campbell már 1976-ban kimutatta, hogy a kaszinókban történő szerencsejáték hatására az idősek önbecsülése növekszik. 
Különösen az online szerencsejátékok lehetnek alkalmasak idősek számára. McKay (2005) kimutatta, hogy az idősebb szerencsejátékosok morális tényezők következtében valószínübben titkolják viselkedésüket, az online szerencsejátékok anonimitása ebben segítségükre lehet. Továbbá a mozgásban korlátozott idősek számára az online szerencsejátékok azonnali elérhetősége erős motivációs bázist jelenthet. Az elérhetőség és az anonimitás az online szerencsejátékok vonzó jellemzői (Körmendi, 2015), melyek fontosak lehetnek az idős szerencsejátékosok számára is.

\section{Kognitív stimuláció}

Az időskori szerencsejáték egyik fontos motivációs alapja lehet tehát az unalom elkerülése. A szerencsejáték önmagában kognitív stimulációt jelent, annak ellenére, hogy a legtöbb játékban a kognitív képességeknek nincs szerepe, a kimenetel kizárólag a véletlenen múlik (Körmendi, 2009). Ugyanakkor a játékosoknál megjelenő „kontroll illúziója” (hiedelem, mely szerint képesek befolyásolni a szerencsejáték kimenetelét) stratégiák, tervek kialakításához és kipróbálásához vezet. Sok szerencsejátékos füzetbe könyveli az egyes menetek eredményeit, melyek alapján stratégiákat állítanak fel. Így a játék megfelelő kognitív stimulációt biztosít az idősek számára. További arousal növekedés történhet a szerencsejáték közben bekövetkező úgynevezett másodlagos megerősítésektől. A szerencsejátékok az intermittáló megerősítési mintázatot használják, a megerősítéshez (nyeréshez) szükséges játszmák száma folyamatosan változik. Az intermittáló megerősítési mintázatban találhatunk úgynevezett másodlagos megerősítéseket, amelyek célja az izgalom további fokozása. Ilyenek lehetnek például a majdnem nyertes kimenetelek, vagy a jackpotok (Körmendi és Kurucz, 2010; Kurucz és Körmendi 2012; Körmendi és Kurucz, 2012). Hatásukra a játékos szerencsésebbnek érzi magát és szívesen folytatná a játékot.

\section{Személyiségjellemzők}

Tira, Jackson és Tomnay (2013) félig strukturált mélyinterjút készítettek 56-85 éves szerencsejátékkal rendszeresen játszó idősekkel, akiknél a szerencsejátékos viselkedés a késői életévekben jelent meg. Három jellemző karaktertípust azonosítottak az idős szerencsejátékosok között eltérő pszichodinamikával, triggerekkel és szerencsejátékos viselkedéssel.

Az első fejlődési ösvény esetében jellemzőek a nagyobb veszteségek, melyek lehetnek például betegségek a családban, krízishelyzetek, nagymértékü stressz vagy olyan jelentős kapcsolati problémák, mint a manipulatív, kihasználó vagy abuzív partner. A szerencsejáték 
legfőbb triggere a veszteségek hatására kialakuló negatív érzelmek, elsősorban kétségbeesés, magány, depresszió vagy düh. Ebben a csoportban tehát a szerencsejáték mögötti motiváció a negatív érzések csökkentése vagy elkerülése a szerencsejátékos viselkedéssel. Ezért a játék során átélt pozitív tapasztalatok kevésbé fontosak, a nyeremények nem váltanak ki örömet vagy elégedettségérzést. A csoportba tartozó személyek nem vágynak nyereményekre, üresnek és érzelemmentesnek érzik magukat szerencsejáték közben. A szerencsejáték azonban lehetőséget biztosít az egyedüllétre, a nyugalomra és a negatív érzésektől való menekülésre. Jellemzően az életkörülmények javulásával és a stressz csökkenésével a szerencsejáték gyakorisága is csökken.

A másik fejlödési ösvény esetében a legfontosabb trigger a magány és az unalom érzése. Az egyén szeretne környezetén változtatni és a szerencsejáték erre lehetőséget biztosít. Ezért ebben a csoportban a szerencsejáték által nyújtott megerősítések különösen fontosak, a nyeremények megtörik az unalmat és a szerencse izgatottá teszi a személyt. Abban az esetben, ha a szerencsejátékos karrier korai szakaszában a szerencse és a nyeremények nincsenek jelen a fenti csoporttal szemben itt megtörténhet, hogy az egyén felhagy a szerencsejátékkal. A csoportba tartozók számára hamarosan a szerencsejáték válik egy kiemelkedő szórakozási lehetőséggé, így hanyagolják családtagjaikat, programjaikat.

Végül a harmadik fejlődési ösvény esetében kompulzív prediszpozíciókat találunk a személyiségben, mely ,addiktív személyiséget” eredményez. A csoportba tartozókra jellemző szenvedélybetegség diagnózisa a családban, kompulzív viselkedésformák, kockázatvállalás és alacsony önkontroll. A játék során nagy tétekkel fogadnak, és nincsenek azonosítható triggereik sem. A sóvárgás spontán jelenik meg, akár stresszmentes időszakban. A szerencsejáték kimenetelei szintén nem befolyásolják motivációikat. A szerencsejátékos karrier ebben a csoportban gyorsabban alakul, mint a másik két csoport esetében. Az elvonási tünetek (pl kézremegés, düh) és a kognitív beszükülés inkább erre a csoportra jellemzőek, a játék hatására ezek csökkennek.

\section{Következtetések}

Az idős szerencsejátékosok a kognitív folyamatok tekintetében egyértelmüen különböztek a fiatalabb szerencsejátékosoktól. A szerencsejátékosoknál kognitív torzítások figyelhetőek meg, melyek hozzájárulnak a kórkép kialakulásához és fennmaradásához. A játékosok hibás következtetéseket vonnak le a játéktapasztalatokkal kapcsolatban, a kognitív torzítások a szerencsejáték eredményének kontrollálására és a kimenetel bejóslására irányulnak. A szerencsejátékosokra jellemző központi hiedelem a „kontroll illúziója”, melyben 
azt gondolják, hogy képesek befolyásolni a szerencsejáték kimenetelét a kívánt irányba. A kontroll illúzióján belül azonban több kognitív torzítás is található, melyek különböző módokon járulnak hozzá a kórkép kialakulásához és fennmaradásához (Körmendi, 2010). Mindezek a gondolatok kevésbé azonosíthatóak az idős szerencsejátékosoknál, a szerencsével és a nyeréssel kapcsolatban racionális gondolatokat mutattak. Az eredmények a kognitív terápián belül vezethetik a terapeuta terápiás stratégiáját. A játékosok irracionális gondolatait átkeretező stratégia a kognitív átstrukturálás, melyet a szókratészi dialógus segítségével végeznek (Körmendi és Pataky, 2012). Az idős szerencsejátékosoknál megfigyelt véletlennel kapcsolatos racionális hiedelmek következtében a kognitív terápiának inkább a szerencsejátékos viselkedést elindít gondolatok azonosítására és megállítására kellene fókuszálnia. A pozitív terápiás változások Svensson (2011) alapján gyorsabban jelennek meg a fiataloknál, mint az időseknél. Tira, Jackson és Tomnay (2013) mintájukban találtak olyan idős játékosokat, akik idegesítőnek, fárasztónak ítéltek olyan szerencsejátékkal kapcsolatos ingereket (például hang és fényhatásokat), amelyeket korábban természetesnek és szórakoztatónak tekintettek. Ezek az eredmények a spontán remisszió folyamatának részeként tekinthetőek, mely megfigyelhető hosszabb szerencsejátékos karrier esetén. A spontán remisszió a szerencsejátékkal kapcsolatos negatív érzések (büntudat, düh, szorongás és szégyen) következtében indul el (Körmendi és Pataky, 2012).

Az időseknél megjelenő szerencsejátékkal kapcsolatos racionális gondolatok és a zavaró szerencsejátékkal kapcsolatos ingerek alátámasztják a szerencsejátékkal kapcsolatos problémák enyhébb megjelenését az idősebb korosztályban. Granero és mtsai (2014) szintén arra a következtetésre jutottak, hogy a szerencsejátékkal kapcsolatos problémák gyakran nem krónikusak és stabilak időskorban, inkább epizódikusnak tekinthetőek. A mintában egy idősebb szerencsejátékos például több mint 20 éve játszott, azonban csak 7 éve jelentkeztek nála problémák. Slutske (2003) is hasonló következtetésre jutott korábban. Továbbá Rossow és Hansen (2003) kimutatta, hogy a szerencsejátékos karrier progressziója gyorsabb a fiatalabbaknál, mint az időseknél, amely szintén kevésbé impulzív, tudatosabb szerencsejátékos viselkedésre utal időseknél.

Az időskori szerencsejáték gyakran környezeti triggerek hatására alakul ki, ezért a prevenciónak is szükségszerü környezeti elemeket megcélozniuk. Az aktivitás, a hasznosság érzése és a kielégítő szociális interakciók hatékonynak bizonyulhatnak a szerencsejátékkal kapcsolatos problémák megelőzésében.

A vonatkozó tanulmányok leggyakrabban homogén csoportként tekintenek az idősebb szerencsejátékosokra (Volberg és Moore, 1999). Azonban fontos lenne további alcsoportok 
létrehozása a vizsgált populáción belül bizonyos változók mentén (Körmendi, 2010). A legfontosabb változónak a preferált játéktípus tűnik, mivel a leggyakrabban választott játéktípus jellegzetes karakterisztikái (strukturális és szituációs jellemzői) lényegesek lehetnek a szerencsejátékos számára. Az addikció pszichoanalitikus elmélete alapján a függőség tárgya a személy belső szükségleteit, hiányzó pszichés struktúráit pótolja, így a különböző játéktípusokat preferálók viselkedése, kognitív stílusa és érzelmi mintázatai eltérhetnek egymástól akár az idős szerencsejátékosok csoportján belül is. Erre példa Tira, Jackson és Tomnay (2013) kutatása, ahol három különböző fejlődési ösvényt is azonosítottak.

Az időskori szerencsejátékkal kapcsolatos eredmények még nem elégségesek egyértelmü következtetések levonására. Fontos jövőbeli kutatási területek lehetnek a motivációs bázis és a vulnerabilitási faktorok meghatározása, valamint különböző terápiás intervenciók használhatóságának megállapítása. Ugyanakkor a tanulmányokat áttekintve megfogalmazhatjuk, hogy a felnőttkori szerencsejátékkal kapcsolatos eredmények nem generalizálhatóak az időskori szerencsejátékosokra. A két csoportok különbözhet a pénzügyi, családi problémák kialakulása és lefolyása tekintetében, de feltehetőleg az időskori szerencsejátékot számos speciális trigger aktiválhatja (például egy önfeláldozó életút végén a saját élmények fontosságának előtérbe kerülése), melyeknek fiatalabb szerencsejátékosoknál kevesebb a relevanciája. Hasonlóképp a gyermekektől való földrajzi távolság unalmat, magányt eredményezhet, mely a vonzó szerencsejátékos közeg felé irányíthatja az idős személyt. Az idősebb szerencsejátékosok szerencsével kapcsolatos racionális hiedelmei és óvatosabb pénzkezelési stratégiái arra utalnak, hogy számukra a pénzszerzés, mint motiváció kevésbé valószínűleg játszik szerepet, mint fiatalabb szerencsejátékosok esetében.

\section{Irodalomjegyzék}

1. American Gaming Association. (2000): State of the States: The AGA Survey of Casino Entertainment. http://www.americangaming.org/assets/files/ AGA.

2. Bazargan M, Bazargan SH, Akanda M. (2001): Gambling habits among aged African Americans. Clinical Gerontologist 22(3,4): 51-62.

3. Beitz KM, Salthouse TA, Davis HP. (2014): Performance on the Iowa Gambling Task: from 5 to 89 years of age. J. Exp. Psychol. Gen. 143: 1677-1689.

4. Campbell FF. (1976): The Future of Gambling. The Futurist 10

5. Granero R, Penelo E, Stichfield R, Fernandez-Aranda F, Savvidou LG, Fröberg F, 
Aymamí N, Gomez-Pena M, Perez-Serrano M, Pino-Gutiérrez A, Menchón JM, Jimenez-Murcia S. (2014): Is pathological gambling moderated by age? Journal of Gambling Studies 30 (2): 475-492.

6. Grant JE, Kim SW, Odlaug BL, Buchanan SN, Potenza MN. (2009): Late-onset pathological gambling: clinical correlates and gender differences. Journal of Psychiatric Research 43 (4): 380-387.

7. Johansson A, Grant JE, Kim SW, Odlaug BL, Götestam KG. (2009): Risk factors for problematic gambling: A critical literature review. Journal of Gambling Studies 25 (1): $67-92$.

8. Körmendi A. (2011): A kóros játékszenvedély kognitív megközelítése. Debreceni Egyetemi Kiadó, Debrecen.

9. Körmendi A. (2009): A kognitív átstruktúrálás jelentősége és lehetőségei a kóros játékszenvedély terápiájában. Psychiatria Hungarica 24 (1): 60-67.

10. Körmendi A., Kuritárné SZI (2007): Kóros játékszenvedély: összefoglaló tanulmány az aktuális kutatásokról Psychiatria Hungarica 22 (5): 344-365.

11. Körmendi A. (2015): Internet Gambling: Current Research Findings and Implications. Journal of Behavioral Addictions 4(1): 32-34.

12. Körmendi A., Kurucz GY. (2010): A "majdnem nyertem" másodlagos megerősítés vizsgálata nem szerencsejátékos mintán. Pszichológia 30 (4): 335-348.

13. Körmendi A, Kurucz GY. (2012): The role of temperament and near-miss in playing a simulated slot machine: the case of betting behavior. In: The psychology of gambling: New research pp. 139-148. Ed.:Cavanna A. New York,

14. Körmendi A (2010): Pseudo skills among gamblers. In: Collection of Psychological Studies pp. 18-23. Ed.: Nagyová LZ. Center Print, Debrecen.

15. Körmendi A, Pataky N. (2012): A kóros játékszenvedély terápiája. Pszichológiai Szemle 67 (3): 519-540.

16. Körmendi A. (2009): A szerencsejátékok strukturális és szituációs jellemzői. Alkalmazott Pszichológia 11 (3-4): 19-35.

17. Körmendi A. (2010): Játékszenvedély és Cloninger pszichobiológiai modellje. In: Pszichológiai Metszetek pp. 78-86. Ed.: Balogh L, Koncz I, Mező F.. Professzorok az Európai Magyarországért Egyesület, Debrecen.

18. Kranes D. (1995): Play grounds. Special issue: Gambling: Philosophy and policy. Journal of Gambling Studies 11 (1): 91-102.

19. Kurucz GY, Körmendi A. (2012): Can we perceive near miss? Journal of Gambling 
Studies 28 (1): 105-111.

20. McKay C. (2005): Double jeopardy:Older women and problem gambling. International Journal of Mental Health and Addiction 3: 35-53.

21. McNeilly DP, Burke WJ. (2001): Gambling as a social activity of older adults. International Journal of Aging and Human Development 52 (1): 19-28.

22. McNeilly DP, Burke WJ. (2000): Late life gambling: the attitudes and behaviors of older adults. Journal of Gambling Studies 16(4): 393-415.

23. Moufakkir O. (2012): An analysis of elderly gamers' trip characteristics and gambling behavior: Comparing the elderly with their younger counterparts.UNLV Gaming Research \& Review Journal 10 (2): 63-75.

24. National Gambling Impact Study Commission. (1999): Final report. Available from http://govinfo.library.unt.edu/ngisc/reports/finrpt.html

25. Nixon G, Solowoniuk J, Hagen B, Williams RJ. (2005):“Double trouble”: The lived experience of problem and pathological gambling in later life." Journal of Gambling Issues 14.

26. Nussbaum AM (2013): A DSM-5 diagnosztikai vizsgálat zsebkönyve. Oriold és Társai Kft, Budapest.

27. Petry NM. (2001): A comparison of young, middle-aged, and older adult treatmentseeking pathological gamblers. The Gerontologist 42 (1): 92-99.

28. Philippe F, Vallerand RJ. (2007): Prevalence rates of gambling problems in Montreal, Canada: a look at old adults and the role of passion. Journal of Gambling Studies 23: $275-283$.

29. Potenza MN, Steinberg MA, Wu R, Rounsaville BJ, O’Malley SS. (2006): Characteristics of older adult problem gamblers calling a gambling helpline. Journal of Gambling Studies 22: 241-254.

30. Rossow I, Hansen M (2003): Entertaintment with an aftertaste. Young people and gaming (NOVA Report 1/2003). Oslo: Norwegian Institute for Research into Childhodd, Welfare and Aging. support Line's Annual Report.

31. Slutske WS, Jackson KM, Sher KJ (2003): The natural history of problem gambling from age 18 to 29. Journal of Abnormal Psychology 112 (2): 263-274.

32. Svensson O. (2011): Gambling: Electronic friends or a threat to one's health and personal development? International Journal of Qualitative Studies on Health Wellbeing 6: 2 . 
33. Tira C, Jackson AC, Tomnay JE. (2014): Pathways to late-life problematic gambling in seniors: a grounded theory approach. The Gerontologist 54 (6) : 1035-1048.

34. Volberg R. (1994): The prevalence and demographics of pathological gamblersimplications for public health. American Journal of Public Health 84: 237-241.

35. Volberg RA, Gupta R, Griffiths MD, Ólason DT, Delfabbro P. (2010): An international perspective on youth gambling prevalence studies. International Journal of Adolescent Medicine and Health 22(1): 3-38.

36. Volberg RA, Moore WL. (1999): Gambling and problem gambling in Washington State: a replication study, 1992 to 1998, report to the Washington State Lottery. Gemini Research, Ltd.

Szerző: dr. Pék Győző PhD

Debreceni Egyetem, Pszichológiai Intézet, Személyiség és Klinikai Pszichológia Tanszék Cím: 4032 Debrecen, Akadémia utca 41

email cím: viktorbaker55@gmail.com

telefonszám: 06 30- 3233638 